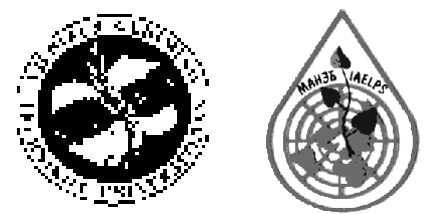

\title{
TWO-PHASE MODELLING OF THERMAL DISSIPATION IN A NATURAL BASIN
}

\author{
Pranas Baltrènas $^{1}$, Petras Vaitiekūnas ${ }^{2}$, Vladislovas Katinas ${ }^{3}$, Antanas Markevičius ${ }^{4}$ \\ 1, 2 Dept of Environmental Protection, Vilnius Gediminas Technical University, \\ Sauletekio al. 11, LT-10223 Vilnius-40, Lithuania.
${ }^{3,}{ }^{4}$ Renewable Energy Laboratory, Lithuania Energy Institute, Breslaujos g. 3, LT-44403 Kaunas-35, Lithuania. E-mail:vaitiek@itpa.lt,marke@isag.lei.lt

Received 12 Jun 2002; accepted 21 May 2004

\begin{abstract}
The state of two-phase flow 'liquid-gas' has been modeled numerically by the three-dimensional method of complex research of heat and mass transfer. This allows examining the interaction of some transfer processes in a natural cooling basin (the Drūkšiai lake): the wind power and direction, variable water density, the coefficient of heat conduction and heat transfer of the water-air interface. Combined effect of these natural actions determines the heat amount that the basin is able to dissipate to the surrounding atmospheric media in thermal equilibrium (without changes in the mean water temperature).

This paper presents a number of the most widely used expressions for the coefficients of vertical and horizontal heat transfer. On the basis of stream velocity and mean temperature profiles measured in the cooling pond as well as on that of their time variations suggestions are made that the mixing rate at the water surface is caused by natural space - time variation of the wind, and can be described by the value of eddy viscosity coefficient $-1 \mathrm{~m}^{2} / \mathrm{s}$ (numerical modeling with $0,9-1,3 \mathrm{~m}^{2} / \mathrm{s}$ ). The wind influences the surface of the lake according to the experimental data, i e $1-3 \%$ of the mean wind velocity. The model applies to the weakly wind, approximately $1-5 \mathrm{~m} / \mathrm{s}$ of the mean wind velocity.

Comparison of experimental and numerical results showed a qualitative agreement. For a better quantitative approximation, it is necessary to have more boundary conditions variable with time and to solve unsteady set equations for transfer processes.
\end{abstract}

Keywords: hydrodynamics, Computational Fluid Dynamics (CFD), numerical simulation, three-dimensional processes, two-phase flows, lake as a cooler, mass and heat exchange.

\section{Introduction}

Hydrothermal processes in a cooling pond are determined by the heat-and-mass exchanger at the waterair interface, together with thermal processes inside the water volume of the pond. Inverse relations are observed between the two sets of processes, as the surface temperature determines the intensity of cooling, and this influences the temperature field of the pond together with the conditions of stratification's different densities of the streams, and turbulent transfer [1].

The success of a mathematical simulation based on general relations of transport may depend on a correct problem-stating on the basis of a correct choise of adequate initial conditions. The most important conditions for both remote regions and the whole cooling pond are: heat transfer to the atmosphere, the parameters of turbulence, heat balance, that is loss and increase of heat.
The former terms are found from convection, turbulent heat transfer, evaporation and inverse radiation in a longwave spectrum. An increase of heat occurs whenever a volume of heated water is discharged by a thermal or nuclear power plant as well as from solar and atmospheric radiation [1,2].

The aim of this paper is by applying CFD codes [3] to present a simulation of a two-phase mathematical model of hydrothermal processes in a cooling pond, including the effects of three-dimensional (3D) structure features of the transport, power and direction of the wind, temperature-dependent water density, and heat conduction at the water-air interface.

\section{Solution techniques and governing equations}

2.1. Equations. In a general approach with recirculation of streams and heat transfer, the problem is solved 
as the $3 \mathrm{D}$ set of the Navier-Stokes equations and energy equation for a two-phase theoretical model. A general expression is $[3,4]$ :

$$
\operatorname{div}\left(r_{i} \rho_{i} \overrightarrow{\mathbf{V}}_{i} \Phi_{i}-r_{i} \Gamma_{\Phi} \operatorname{grad} \Phi_{i}\right)=r_{i} S_{\Phi i}
$$

where $r_{i}$ - volume part of phase $i ; \rho_{i}$ - density of phase $i, \mathrm{~kg} / \mathrm{m}^{3} ; \Phi_{i}-$ dependent variable of phase $i: 1$ - for continuity equation, $U, V, W$ - for impulse in directions $x, y$ and $z, \mathrm{~m} / \mathrm{s} ; H$ for enthalpy; $\overrightarrow{\mathbf{V}}_{i}-$ velocity vector of phase $i ; \Gamma_{\Phi}-$ exchange coefficient of variable $\Phi ; S_{\Phi}-$ source term in the flow for variable $\Phi$. The set of (1) consist of differential equations with partial derivatives of Navier-Stokes and heat transfer, and are solved by the technique of finite volumes with specific boundary conditions [3, 4].

The real properties of water will be implemented for accounting the existent links between its density, heat capacity, thermal conductivity, etc, and the temperature (water in liquid state). This linking and establishment of conditions that simulates the action of gravity will establish conditions for possible formation of a natural convection phenomenon and buoyancy forces.

The program codes used evaluate the density of water as a function of temperature $t$ [5]:

$$
\begin{aligned}
\rho= & \left(999,83952+16,945176 t-7,9870401 \cdot 10^{-3} t^{2}-\right. \\
& 46,170461 \cdot 10^{-6} t^{3}+105,56302 \cdot 10^{-9} t^{4}- \\
& \left.280,54253 \cdot 10^{-12} t^{5}\right) /\left(1+16,879850 \cdot 10^{-3} t\right),
\end{aligned}
$$

where $\rho$-density, $\mathrm{kg} / \mathrm{m}^{3}, t-$ water temperature ${ }^{\circ} \mathrm{C}$. The existence of a density gradient combined with a body force as the gravity action may cause a buoyancy force responsible of a free convection phenomenon which may be important in the fluid motion. However, it will be a good approximation to consider constant other water properties, as thermal conductivity or heat capacity, because of a less effect of their respective gradients on the fluid motion.

They simulate turbulent flows and laminar transient flows with increased turbulence of a free flow. These parameters are very important in the transfer processes of a cooling pond.

When simulation includes the hypothesis of turbulent viscosity, a simple viscosity factor is replaced in transfer relations by an effective viscosity factor

$$
v_{1}=v_{l}+v_{t}
$$

where $v_{l}-$ laminar and $v_{t}-$ turbulent viscosity, $\mathrm{m}^{2} / \mathrm{s}$. For flows of air of about $5 \mathrm{~m} / \mathrm{s}$, we used a constant factor of turbulent viscosity of 6,7 , as in [4].

In our computation we divided the range of integration by a normal line. One of the parts contained 9 horizontal layers in the volume of water and was intended for evaluating the geometry of the shoreline and depth. The other part contained 9 horizontal layers in the volume of air covered over-water flows of air and land, that is velocity, direction and force of the wind with the influence of the nearest relief. The parameters of the pond, hot-water plume and cool water return must be as close as possible to the actual values. In our study we used the flow-rate of the hot-water discharge.

We present an analysis of the effect of a weak wind $(0-5 \mathrm{~m} / \mathrm{s})$ on the hydrothermal behaviour in the pond, for constant values of turbulence in the air:

$$
v_{t}=1,34 \times\left|U_{l o c}\right|
$$

where $U_{l o c}$ is local velocity in the atmosphere and mass transfer in water according to [3].

2.2. Interphase source term. The interphase source con-tains the diffusive (e g, friction, heat transfer) and convective (mass transfer) links between phases. It is formulated in a general form as follows:

$$
S_{I P}=\left(f_{\phi, i}+<m_{j i}>\right)\left(\phi_{i}^{i n t}-\phi_{i}\right),
$$

where $f_{\phi, i}-$ interphase (diffusive) transfer coefficient, $\mathrm{kg} /$ $\mathrm{s} ; m_{j i}-$ net mass transfer rate between phases, $\mathrm{kg} / \mathrm{s} ;<>-$ maximum of 0,0 and the quantity enclosed; $\phi_{i}^{i n t}-$ value of $\phi$ at the interface between phases, $\phi_{i}$ is a bulk phase value of conserved variable $\phi$.

The unit of $S_{I P}$ is $(\mathrm{kg} / \mathrm{s}) \times($ unit of $\phi)$, i e if $\phi$ is velocity, $\mathrm{m} / \mathrm{s}$, the units of $S_{I P}$ are Newtons and if $\phi$ is enthalpy, $\mathrm{J} / \mathrm{kg}$, the units of $S_{I P}$ are Watts. $S_{I P}$, obviously, appears in the equations for each of paired variables, $\phi_{1}$ and $\phi_{2}$, i e:

$$
\begin{aligned}
& S_{I P, 1}=\left(f_{\phi, 1}+<m_{21}>\right)\left(\phi_{1}^{i n t}-\phi_{1}\right), \\
& S_{I P, 2}=\left(f_{\phi, 2}+<m_{12}>\right)\left(\phi_{2}^{i n t}-\phi_{2}\right),
\end{aligned}
$$

where $m_{21}=-m_{12}$.

2.3. Interphase Friction. Ignoring the interphase mass transfer, the interphase source term becomes:

$$
S_{I P}=f_{I P} \times\left(v_{2}-v_{1}\right),
$$

where $S_{I P}$ has units of Newton and $f_{I P}$ is now the interphase drag coefficient between phases in units of $\mathrm{Ns} / \mathrm{m}$ or $\mathrm{kg} / \mathrm{s}$.

2.4. Interphase heat transfer. In many cases the driving force is the temperature difference, and available heat transfer correlations are based upon it. By solving enthalpies $H_{1}$ and $H_{2}$ and ignoring mass transfer the interphase sources become:

$$
\begin{aligned}
& S_{H 1}=h_{12} \times A_{S} \times\left(T_{1}^{i n t}-T_{1}\right), \\
& S_{H 2}=h_{21} \times A_{S} \times\left(T_{2}^{\text {int }}-T_{2}\right),
\end{aligned}
$$

where $h_{12}$ - bulk1-to-interface heat transfer coefficient, $\mathrm{W} / \mathrm{m}^{2} \mathrm{~K} ; h_{21}$ - bulk2-to-interface heat transfer coefficient, $\mathrm{W} / \mathrm{m}^{2} \mathrm{~K} ; A_{S}$ - total interface area, $\mathrm{m}^{2}$. The interface temperatures $T_{1}{ }^{\text {int }}$ and $\mathrm{T}_{2}{ }^{\text {int }}$ can be eliminated via the overall heat transfer coefficient and bulk-to-bulk temperature difference as follows:

$$
S_{H i}=1 \times A_{S} \times\left(T_{2}-T_{1}\right) /\left(1 / C_{1}-1 / C_{2}\right),
$$

where $C_{1}=h_{12}$ and $C_{2}=h_{21}$.

The interphase transfer coefficient $f_{I P}$ is taken to be 
harmonic average of the bulk-to-interface coefficients $C_{1}$ and $C_{2}$. Thus

$$
f_{I P}=2 /\left(1 / C_{1}-1 / C_{2}\right) .
$$

In Phoenics programme two-phase mode, it is common to solve for enthalpy. A source is required in the form:

$$
S_{H i}=h_{12} \times A_{S} \times\left(T_{2}-T_{1}\right),
$$

where $h_{12}-$ the heat transfer coefficient, $\mathrm{W} / \mathrm{m}^{2} \mathrm{~K} ; A_{S}-$ total surface area of particulates, $\mathrm{m}^{2}$; the subscripts 1 and 2 refer to the first and other phase.

\section{Results and consideration}

A variable-step grid was constructed (Fig 1). It covers only a certain part of the surface, and the range of integration with respect to the normal covers a $10 \mathrm{~m}$ layer of water and a $100 \mathrm{~m}$ layer of air, including the nearest relief (with blocking cells).

In this case we evaluated the effect of the wind on the hydrothermal behavior of the lake which comes into play by the influence on the distribution of isotherms. The technique of testing was applied from [2]. Evaluation was made concerning temperature dependence on water density according to experimental correlation (2), water-air heat conduction and the resistance factor of water. Transient equations for transfer processes are simplified according to [6].

A numerical simulation of $33 \times 23 \times 18$ grid system consumes a lot of computer time, therefore, computation was suspended whenever a specific effect of the wind became evident or similar to measurement data at hot water discharge. A closer agreement was found for the case of no wind [4, 7, 8]. Figs 2 a and $2 \mathrm{~b}$ present, respectively, measurement and simulated results of isotherms for the $1 \mathrm{~m} / \mathrm{s}$ southwest wind. Figs $3 \mathrm{a}$ and $3 \mathrm{~b}$ show respectively the water surface velocity vector distribution and wind horizontal vector field $0,25 \mathrm{~m}$ above the water surface. Fig 4 presents the predicted movement of water surface at a mean southwestern wind velocity of $5 \mathrm{~m} / \mathrm{s}$.

For predicting the effect of the wind on the water surface, we used a constant water heat transfer coefficient. Mixing of a hot and cool water in the lake is a complicated process, and the wind makes it even more complicated, as it introduces waves and variable depth. Predictions cannot be in good agreement with the measurement results because the wind blowing directions are variable with time, and the actual hydrothermal state of the pond is a continuously varying behavior. For this reason a variable coefficient of water heat transfer must be introduced into future predictions.

\section{Conclusions}

1. The earlier code of numerical elliptic equations was used to construct a primary numerical model of hydrothermal dynamics in the Drūkšiai lake, in the re-

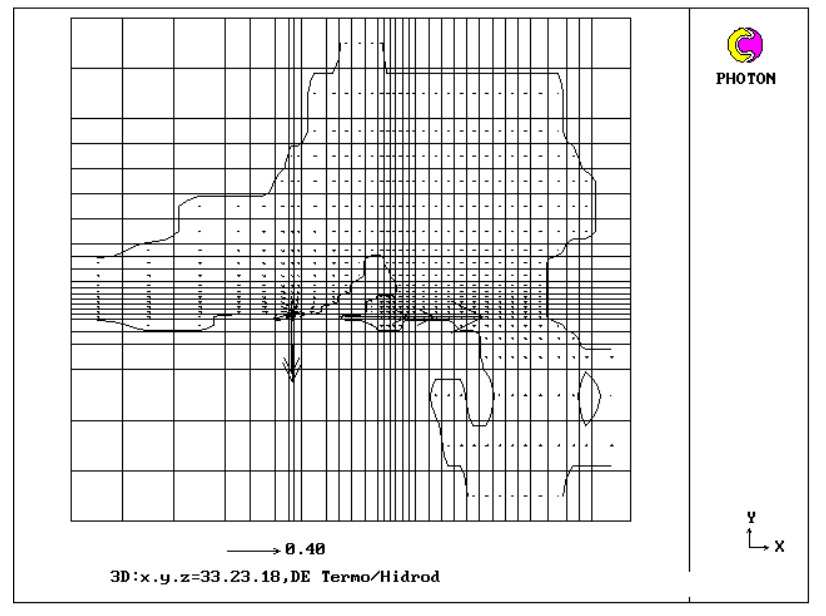

Fig 1. Computational representation of the basin, inlet and outlet velocity vectors (reference scale $-0,40 \mathrm{~m} / \mathrm{s}$ )

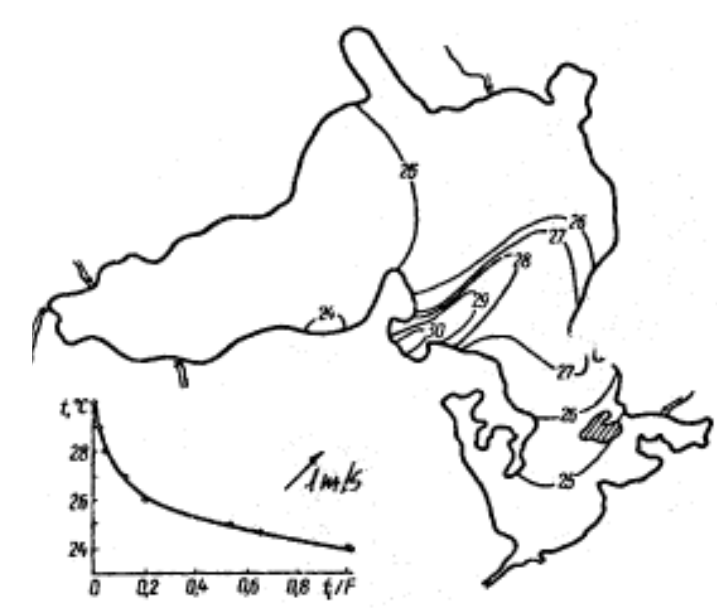

a

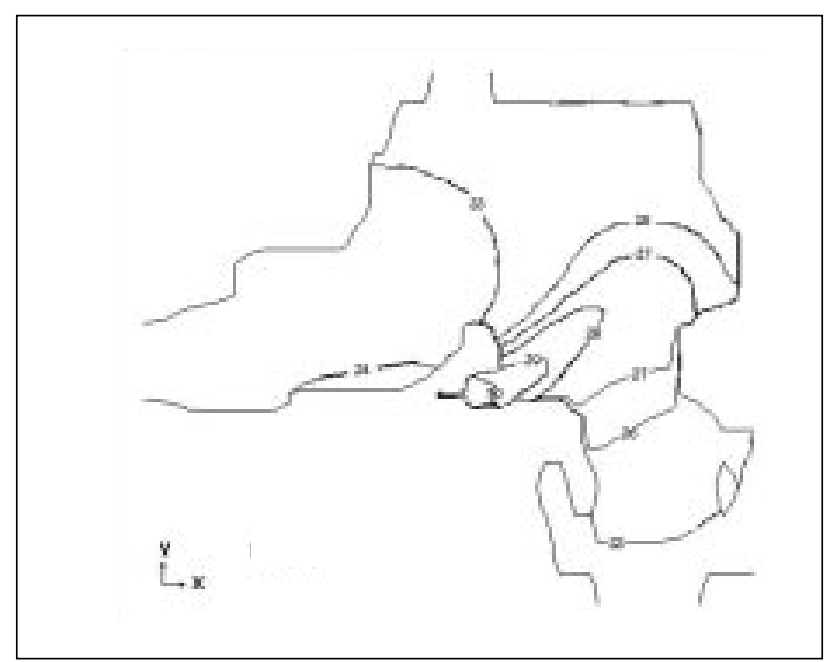

b

Fig 2. Temperarure distribution on the surface of the Drūkšiai lake for an average soutwestern wind velocity of $1 \mathrm{~m} / \mathrm{s}$ : a - measured isotherms [2]; b - predicted isotherms. The air temperature is $23,9^{\circ} \mathrm{C}$ 


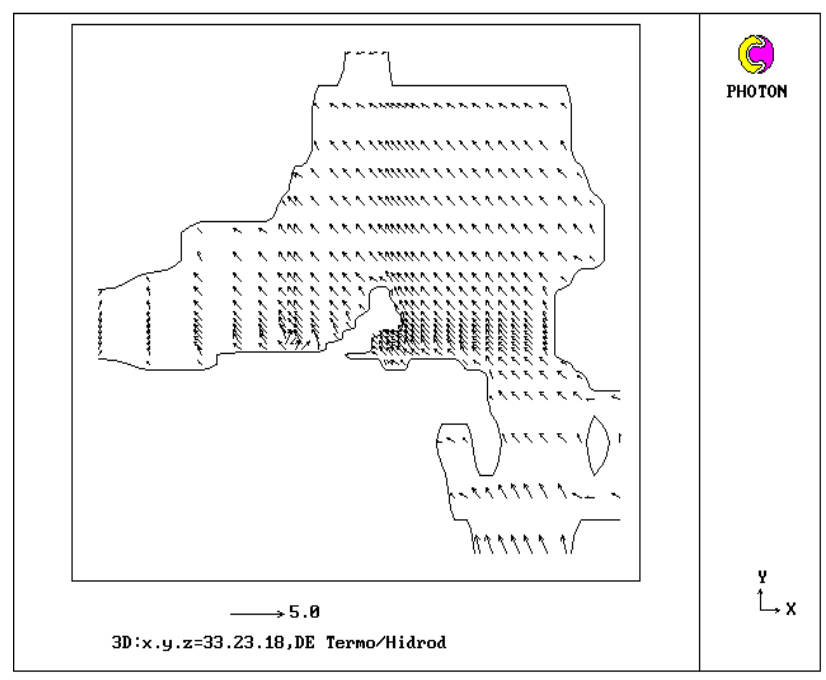

a

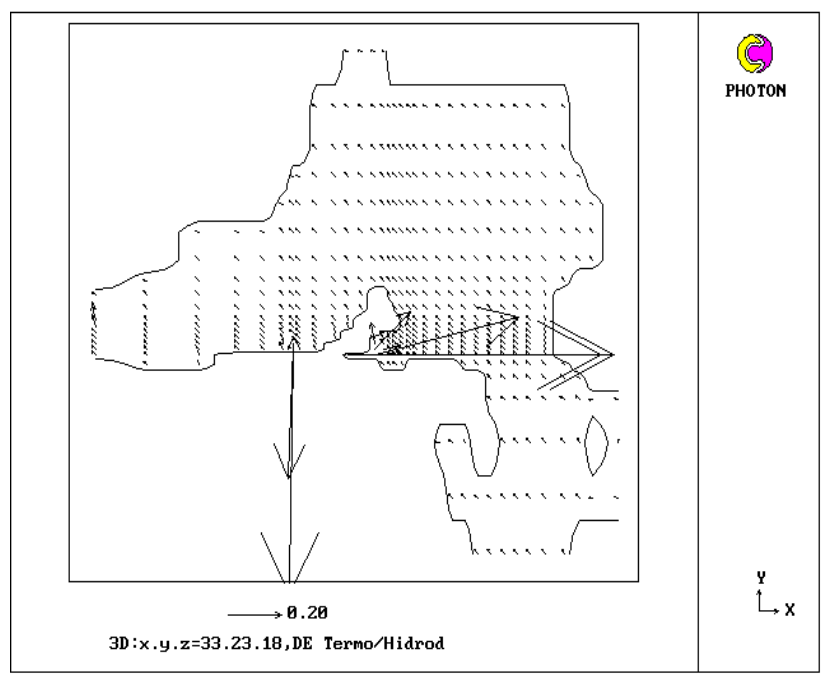

b

Fig 3. Movement of fluids at a mean southeastern wind velocity of $1 \mathrm{~m} / \mathrm{s}$ : a - horizontal vector field in the air zone of $0,25 \mathrm{~m}$ above water surface (vector reference scale $-5 \mathrm{~m} / \mathrm{s}$ ); b - water surface velocity vectors (reference scale $-0,2 \mathrm{~m} / \mathrm{s}$ )

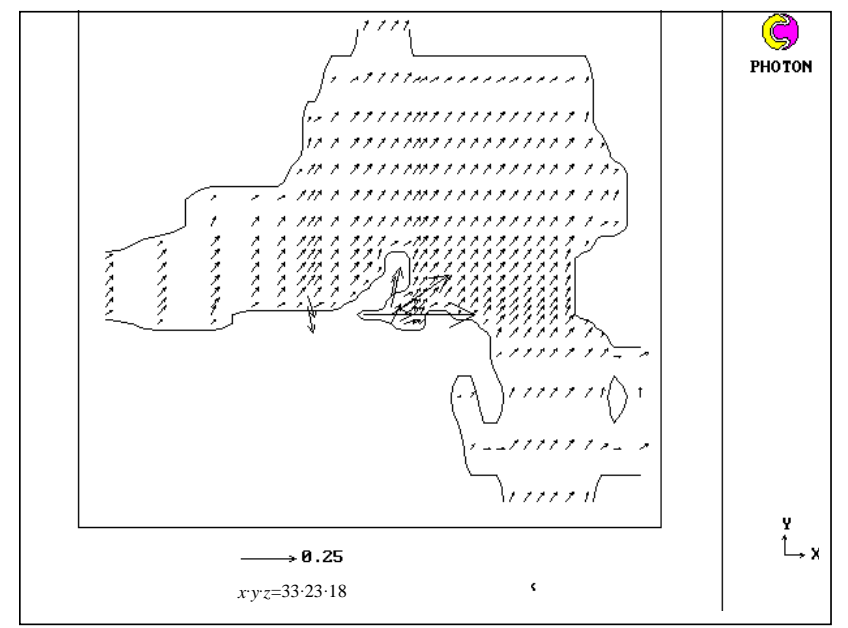

Fig 4. Predicted movement of water surface at a mean southwestern wind velocity of $5 \mathrm{~m} / \mathrm{s}$ (reference scale $0,25 \mathrm{~m} / \mathrm{s})$ gion of the hot-water discharge. The CFD codes were applied for the numerical solution of a two-phase 3D mathematical model of the flow. The solutions can evaluate the effect of the wind, temperature-dependent water density, water-air heat conduction, water mass transfer and the ground geometry.

2. Analysis of numerical solutions for the hydrothermal processes in the Drūkšiai lake and their comparison with the test points suggest the influence of the wind, heat conduction from water to air, variable water density, water mixing and partially that of the geometry of the shore-line on the simulation results which are qualitatively similar to those at the test points. To approximate prediction to the actual state, possible timedependent boundary conditions should be included.

\section{References}

1. Drižius, M. R. Hydrothermics of cooling ponds (Гидротермический режим водохранилищ-охладителей). Vilnius: Mokslas, 1985. 107 p (in Russian).

2. Ecosystem of the cooling pond of the Ignalina Nuclear Power Station in the initial period of its operation. (Ignalinos atominès elektrinès šaldomojo tvenkinio ekosistemos būklè pradiniu jos eksploatacijos periodu). Vol 10. Part 1. Vilnius: Lithuanian Academy of Sciences, 1992. 246 p. (in Lithuanian).

3. Montenegro, H. S.; Choucino, M. A. Thermal dissipation in a natural basin. The PHOENICS Journal of Computational Fluid Dynamics \& Its Applications, Vol 7, No 3, 1994, p 14-36.

4. Vaitiekūnas, P.; Petkevičienè, J.; Katinas, V. A numerical simulation of three-dimensional hydrothermal processes in a cooling pond. The PHOENICS Journal of Computational Fluid Dynamics \& Its Applications, Vol 11, No 3, 1998, p 348-354.

5. Vaitiekūnas, P.; Petkevičienè, J.; Katinas, V. Numerical simulation of hydrothermal processes in the Drūkšiai lake. 1. Computational procedure. Energetics (Energetika), No 4, 2000, p 42-52 (in Lithuanian).

6. Vaitiekūnas, P.; Katinas, V.; Markevičius, A. Simulation of convective-conductive heat transfer in a natural basin. Environmental Engineering and Landscape Management, Vol XII, No 2, 2004, p 58-62.

7. Vaitiekūnas, P.; Petkevičiené, J. Two-phase numerical modeling of heat exchange in a natural basin. In: Advances in Heat Transfer Engineering, Ed. B. Sunden and J. Vilemas. The $4^{\text {th }}$ Baltic Heat Transfer Conference, 2527 August 2003, Kaunas, 2003, p 435-440.

8. Baltrènas, P.; Vaitiekūnas, P.; Petkevičienè J. Numerical simulation of hydrodynamic processes in the lake of Drūkšiai. Environmental Engineering (Aplinkos inžinerija), Vol IX, No 2, 2001, p 117-123 (in Lithuanian). 


\section{ŠILUMINĖS DISIPACIJOS NATŪRALIAME BASEINE DVIFAZIS MODELIAVIMAS}

\section{P. Baltrènas, P. Vaitiekūnas, V. Katinas, A. Markevičius}

\section{$\mathrm{S}$ a n t r a u k a}

Dvifazis matematinis modelis skystis-dujos taikomas atliekant skaitinị trimačių pernešimo procesų modeliavimą. Nagrinejjama pernešimo procesams įtakos turinčių veiksnių sąveika, ju itaka masès ir šilumos mainams natūraliame baseine-aušintuve: vèjo stiprumas ir kryptis, pagal temperatūrą kintantis vandens tankis, šilumos mainai su atmosfera, trinties ir šilumos mainu vandens ir oro skiriamajame paviršiuje koeficientai.

Rastos ir pateikiamos vertikaliujų ir horizontaliujų turbulentiniu mainų koeficientu priklausomybès. Remiantis srovių ir vidinių temperatūrų profilių matavimų duomenimis nustatyta, kad vidutinio stiprumo nepastovus vejjas sukelia vandens paviršiuje maišymąsi, kurị galima įvertinti $1 \mathrm{~m}^{2} / \mathrm{s}$ dydžio turbulentiniu klampiu (skaičiavimuose taikytas turbulentinis klampis $0,9-1,3 \mathrm{~m}^{2} / \mathrm{s}$ ). Vejo impulso ittaka vandens paviršiui, pagal eksperimentinius duomenis, turi būti $1-3 \%$ vidutinio vejjo greičio. Matematinis modelis skirtas pernašos procesams modeliuoti esant $1-5 \mathrm{~m} / \mathrm{s}$ vidutinio vejjo greičiams. Palyginus eksperimentinių ir teorinių tyrinejjimų rezultatus akivaizdus ju kokybinis sutapimas. Kiekybinis rezultatų sutapimas būtų tikslesnis turint daugiau ịvairių veiksnių ribinių laike kintamų sąlygų bei sprendžiant nenuostoviąsias pernašos lygtis.

Raktažodžiai: hidrodinamika, skaičiuojamoji fluidų dinamika, skaitinis modeliavimas, trimačiai procesai, dvifaziai srautai, baseinas-aušintuvas, masès ir šilumos mainai.

\section{ДВУХФАЗНОЕ МОДЕЛИРОВАНИЕ ТЕПЛОВОЙ ДИССИПАЦИИ В НАТУРАЛЬНОМ БАССЕЙНЕ}

П. Балтренас, П. Вайтекунас, В. Катинас, А. Маркявичюс

P е 3 ю м е

Двухфазная математическая модель жидкость-газ использована для численного моделирования трехмерных процессов переноса массы и тепла. Исследуется взаимосвязь факторов, влияющих на процессы переноса, их влияние на массо- и теплообмен в натуральном бассейне-охладителе, скорость и направление ветра, переменная вязкость воды, теплообмен с атмосферой, коэффициенты трения и теплообмена на поверхности раздела фаз.

В статье использованы широко применяемые выражения для вертикального и горизонтального коэффициентов теплообмена. На основе измерений профилей усредненной скорости и температуры найдено, что нестабильный ветер средней силы производит перемешивание водной поверхности, которое можно оценить турбулентной вязкостью в $1 \mathrm{~m}^{2} / \mathrm{c}$ (при моделировании использовано 0,9-1,3 $\mathrm{m}^{2} / \mathrm{c}$ ). Влияние импульса ветра на водяную поверхность согласно экспериментальным данным составляет 1-3 \% средней скорости ветра. Обе модели предназначены для моделирования процессов переноса при умеренном ветре со средней скоростью в $1-5 \mathrm{~m} / \mathrm{c}$.

Сравнение теоретических и экспериментальных результатов показало качественное их совпадение. Для более точного количественного совпадения необходимо наличие большего количества граничных условий, изменяющихся во времени, а также решение нестационарных уравнений переноса.

Ключевые слова: гидродинамика, вычислительная динамика жидкостей, численное моделирование, трехмерные процессы, двухфазный поток, бассейн-охладитель, массо- и теплообмен. 